\title{
Strategi Pembelajaran Ips Dimasa Pendemi Covid- 19 \\ Smp Negri 3 Danau Panggang
}

\author{
Abdurrahim \\ Universitas Lambung Mangkurat
}

2021

\begin{abstract}
Abstrak
Sejak maraknya virus corona (covid-19) yang mulai menyebar kesegala arah yang ada dipermukan bumi, mengharuskan manusia untuk beradaptasi membuat sesuatu aktivitas baru yang bahkan sebelumnya belum pernak terpikirkan oleh seorangpun, bagaimana tidak aktivitas yang dulu dilakukan dengan tanpa batas serta dilakukan di luar berubah menjadi aktivitas yang hanya boleh dilakukan di dalam rumah dan dengan batasan - batasan yang diberlakukan untuk mencegah penularan virus covid- 19. Covid- 19 tidak hanya berdampak pada satu aspek saja akan tetapi hampir semua sendi kehidupan kena dampak dari adanya virus- 19 ini tidak terkecuali, pada aspek pendidikan yang mengharuskan perubahan desain pembelajaran yang awalnya tatap muka berubah menjadi pembelajaran daring (Online). Sesuai surat keputasan dari kemendikbud guna memutus rantai penularan covid- 19 ini seluruh sekolah dialihkan mejadi pembelajaran daring. Bebagai macam strategi dilakukan untuk memfasilitasi peserta didik untuk mendapatkan pembelajaran yang efektif. Begitu juga pada sekolah SMP negri 3 Danau Panggang, dimana strategi yang merekan lakukan sedikit berbeda dengan yang lain mengingat berbagai kendala yang dilakukan seperti, koneksi jaringan yang sangat tidak stabil, peserta didik yang terlena akan suasana belajar yang santai sertaa masih baanyak lagi kendala - kendala yang dialami lainnya.
\end{abstract}

Kata kunci : Strategi Pembelajaran, pendidikan Indoneia, covid- 19

PENDAHULUAN

Pembangunan dalam sebuah bangsa merupakan sebuah kewajiban dalam memajukan masyarakatnya. Dalam pelaksanaan pembangunan, banyak melibatkan berbagai macam sendi-sendi kehidupan bangsa seperti ekonomi, politik, pendidikan dan berbagai sendi aspek- aspek yang lainnya. Prioritas dalam 
peningkatan pembangunan dan pendidikan dapat menjadi landasan penting dalam kehidupan masyarakat dimasa depan. Tujuannya adalah untuk dapat bersaing dengan bangsa- bangsa yang sudah mampu memajukan pendidikan dan menjadi kunci dalam kesejahtaraan dan pengembangan berbagai keilmuan.

Sejarah perkembangan dan pembangunan bangsa-bangsa mengajarkan bahwa bangsa yang maju, modern, makmur, dan sejahtera adalah bangsa- bangsa yang memiliki sistem dan praktik pendidikan yang bermutu. Seluruh kegiatan pendidikan, yakni bimbingan pembelajaran, dan latihan diarahkan untuk mencapai tujuan pendidikan. Pendidikan yang bermutu sangat tergantung pada keberadaan guru yang bermutu, yakni guru yang profesional, sejahtera, dan bermartabat.

Dunia pendidikan tidak akan pernah terlepas proses pembelajaran. Pembelajaran dengan kata dasar belajar sebenarnya merupakan proses yang mencakup dua hal yaitu belajar itu sendiri dan mengajar. Kegiatan belajar biasanya difokuskan pada kegiatan siswa dalam pendidikan. Sedangkan mengajar biasanya difokuskan pada kegiatan guru dalam pembelajaran. Meski dewasa ini, kegiatan belajar dan mengajar dapat dilakukan oleh semua pelaku pendidikan tidak hanya guru dan siswa.

Namun berbeda halnya pada kondisi pandemi Covid-19 saat ini mengakibatkan perubahan yang luar biasa, termasuk dalam bidang pendidikan. Seolah seluruh jenjang pendidikan dipaksa bertransformasi untuk beradaptasi secara tiba- tiba drastis untuk melakukan pembelajaran dari rumah melalui media daring (online). Ini tentu bukanlah hal yang mudah, karena belum sepenuhnya siap. Problematika dunia pendidikan yaitu belum seragamnya proses pembelajaran, baik standar maupun kualitas capaian pembelajaran yang diinginkan.

Keberhasilan pembangunan negara salah satu tolak ukurnya adalah keberhasilan pendidikan. Melalui pendidikan, akan melahirkan generasi penerus yang cerdas intelektual maupun emosional, terampil, dan mandiri untuk mencapai pembangunan bangsa ini. Namun muncul polemik masyarakat pada metamorfosa di masa pandemi Covid- 19. Hal ini tentu dirasa berat oleh pendidik dan peserta didik. Terutama bagi pendidik, dituntut kreatif dalam penyampaian materi melalui media pembelajaran daring. Ini perlu disesuaikan juga dengan jenjang pendidikan 
dalam kebutuhannya.

Tak terkecuali juga di sekolah SMP negri 3 Danau Panggang yang saat ini tidak bisa melakukan pembelajaran seperti mana biasanya, pada kesempatan ini saya mencoba untuk mengamati strategi seperti apa yang dilakukan dalam mengatasi polemik yang dihadapi dunia pendidikan saat ini khususnya di SMP negri 3 Danau Panggang. Kenapa seperti itu, karena sekolah SMP ini memiliki letak geografis yang jauh dari jangkauan kota yang menambah kesulitan melaksanakan sekolah dari melalui aplikasi seperti zoom, meet dan lain - lain. Belum lagi kondisi orang tua peserta didik yang perekonomiannya tidak begitu stabil juga menjadi permasalahan yang menjadi tantangan tersendiri bagi para guru SMP negri 3 Danau Panggang ini.

\section{HASIL PENELITIAN DAN PEMBAHASAN}

Seperti yang kita ketahui system pendidikan Indonesia saat ini sedang di tuntut untuk bertranformasi yang dulunya pembelajaran dilakukan secara tatap muka beralih menjadi pembelajaran secara daring (online). Tentunya hal ini menuntut pendidik untuk lebih berenovasi lagi dalam menyeusun pembelajaran agar tujuan pendidikan tetap harus dicapai walaupun system pembelajaran yang dilakukan secara daring, berbagai macam dinamika tentunya akan muncul karena perbedaan letak geografis dan fasilitas sekolah yang berbeda- beda untuk masing - masing sekolah yang ada. Mengapa tidak pebedaan letak geogrfis ini yang nantinya akan mempengaruhi bagamana kelancaran pembelajaran yang akan dilakukan disetiap daerah juga perlu diperhataikan sebabnya tidak semua daerah yang memiliki koneksi jaringan yang kuat dan lancar seperti dikota besar. Selain itu adanya himbawaan pembelajaran daring ini juga menuntuk peserta didik untuk memiliki gejed, Hp, leptop dan lainnya yang digunakan untuk melakukan pembelajaran online yang secara tidak langsung memberi tekanan moril kepada orang tua peserta didik untuk membelikan anaknya gejed.

Hal ini dirasakan oleh dewan guru SMP negeri 3 danau Panggang, meskipun ada himbauan sekolah dilaksanakan daring akan tetapi sekolah ini lebih memilih strategi lain dalam melakukan pembelajaran. Startegi yang saya amati ini adalah strategi sekolah yang tetap melakukan pembelajaran tatap muka akan tetapi 
dilakukan secara terbatas dan berkala dari segi jumlah dan juga waktu pelaksanaannya dan pastinya dilakukn sesuai dengan protocol kesehatan, selain itu pembelajaran juga tidak dilakukan didalam ruangan akan tetapi pembelajaran dilakukan diluar ruangan seperti pembelajaran IPS yang sempat saya amati. Pembelajaran yang dilakukan ditempat - tempat umum seperti dermaga masjid, aula terbuka balai desa bahkan hingga dipelataran rumah warga tentunya dengan izin pemilik rumah. Strategi seperti ini tentunya sangat lambat dalam penyampaian dikarenakan pebelajaran yang dilakukan dalam sekali pertemuan hanya sepertiga dari jumlah keseluruan peserta didk dari keselurannya, selain itu media pembelajaran yang digunakan terbatas bahkan tidak sama sekali menggunakannya karena fasilitas yang kurang memadai dan jauh dari ruangan sekolah menjadi factor penghambat lainnya.

Secara tidak langsung metode pembelajaran yang dilakukan juga hanya menggunakan metode ceramah dan penugasan diakhir petermuan. Walapun sekekali guru menanyakan kepada peserta didik materi - materi yang telah dipelajari, hal ini tentunya ttidaklah sepenuhnya efektif karena pembelajaran yang monutun serta membosankan yang sedikit bnyaknya membuat peserta didik males dalam belajar. Bebagai macam kendala pastia ada ketika system pembelajaran yang berubah, apalagi pembelajaran yang tidak pernah dilaknakan sebelumnya, tentunya memerlukan adaptasi serta penyesesuaian baik bagi pendidik atapun peserta didikk. Hal terbesar kendala pembalajaran ini adalah tingkat ketercapaian dari pembelajaran yang sulit tercapai dan sesuai target seperti biasanya dimana jika tatap muka secara keseluruhan dapat menyelesaikan 8 bab selama satu semester hal yang berbada akan ditemukan dalam strategi pembelajarn kali ini karena pasalnya satu kelas saja bisa mencapai 3 kali bertemu dengan orang yang berbeda - beda dari satu kelas. Kendala lainnya juga waktu dan jumlah orang yang terbatas membuat pembelajaran susah tersampaikan secara langsung untuk keseluruhan peserta didik.

SIMPULAN

Pada pengamatan yang saya lakukansaya mendapati bahwa tidak semua pembelajran daring dapat dilakukan di setiap sekolah khususnya disekolah 
ditempat saya tinggal, para guru lebih memilih starategi lain dalam melakukan pembelajaran disbanding dengan melakukansekolah daring yang belum tentunya semua peserta didik mengerti dan paham akan apa yang disampikan, walaupun tingkat ketercapaiannya juga masih belum 100 persen, paling tidak membantu meminimalisir peserta didik agar tetap mendapatkan pendidikan walaupun dengan cara yang tidak biasa. 


\section{REFERENSI}

ABBAS, E. W. (2014). Pendidikan Karakter.

Abbas, E. W. (2019). Building Nation Character Through Education: Proceeding International Seminar on Character Education.

Ahsani, E. L. F. (2020). Strategi Orang Tua dalam Mengajar dan Mendidik Anak dalam Pembelajaran At The Home Masa Pandemi Covid- 19. Al Athfal: Jurnal Kajian Perkembangan Anak Dan Manajemen Pendidikan Usia Dini, 3(1), 37- 46.

Atsani, K. L. G. M. Z. (2020). Transformasi media pembelajaran pada masa Pandemi COVID19. Al- Hikmah: Jurnal Studi Islam, 1(1), 82- 93.

Azzahra, N. F. (2020). Mengkaji Hambatan Pembelajaran Jarak Jauh di Indonesia di Masa Pandemi Covid- 19.

Jumriani, J., Subiyakto, B., \& Syaharuddin, S. (2019). Social Interaction Sasirangan Traders Village in The City of Banjarmasin as a Learning Resources on Social Studies. The Innovation of Social Studies Journal, 1(1), 65- 77.

Khasanah, D. R. A. U., Pramudibyanto, H., \& Widuroyekti, B. (2020). Pendidikan dalam masa pandemi covid- 19. Jurnal Sinestesia, 10(1), 41- 48.

Subiyakto, B., \& Mutiani, M. (2019). Internalisasi nilai pendidikan melalui aktivitas masyarakat sebagai sumber belajar ilmu pengetahuan sosial. Khazanah: Jurnal Studi Islam dan Humaniora, 17(1), 137- 166.

Subiyakto, B., Syaharuddin, S., \& Rahman, G. (2017). Nilai- Nilai Gotong Royong Pada Tradisi Bahaul Dalam Masyarakat Banjar Di Desa Andhika Sebagai Sumber Pembelajaran IPS. Vidya Karya, 31(2).

Syaharuddin, S., \& Mutiani, M. (2020). Strategi Pembelajaran IPS: Konsep dan Aplikasi. 